\title{
Multikulturalisme dan Kemenangan Thoriq Husler Pada Pilkada Serentak 2015 di Kabupaten Luwu Timur
}

\author{
Fitri Hafsari Zainuddin ${ }^{1}$, Syarifuddin Jurdi ${ }^{1}$, Achmad Abdi Amsir ${ }^{2}$ \\ ${ }^{I}$ Program Studi Ilmu Politik UIN Alauddin Makassar \\ ${ }^{2}$ Program Studi Hubungan Internasional UIN Alauddin Makassar
}

\begin{abstract}
Abstrak
Penelitian ini akan melihat aspek keberagaman dan multikulturalisme dalam pemilu elektoral. Artikel ini melihat ada kecenderungan kemenangan seseorang pada Pilkada karena alasan multikultural, diantaranya ikatan kebersamaan etnis, kesamaan suku dan daerah. Penelitian ini berlangsung di Luwu Timur dan menggunakan pendekatan perilaku politik, politik identitas, teori multikulturalisme, dan teori kekuasaan. Penelitian menggunakan metodologi kualitatif dengan metode pengumpulan data berupa wawancara secara intensif. Hasil penelitian ini menunjukan bahwa pelaksanaan Pilkada Luwu Timur tahun 2015, etnisitas tidak terlalu memainkan peranan penting karena sentimen etnis pemilih relatif kecil. Pemilih bisa menerima kehadiran kepala daerah yang berbeda dengan etnis di luar dirinya. Keadaan di lapangan ditemukan bahwa dalam proses Pilkada, masyarakat cenderung memilih melihat hasil kinerja dari calon dan sosok figur calon. Sosok Thoriq Husler dalam kesehariannya yang hidup di tengah-tengah masyarakat multikultural memiliki rasa toleransi dan simpatik yang tinggi kepada semua kalangan masyarakat. Sehingga beliau dicintai dan diterima oleh semua kalangan etnis di Luwu Timur.
\end{abstract}

Kata Kunci :

Multikulturalisme, Politik Identitas, Pilkada Serentak, Luwu Timur

\section{PENDAHULUAN}

Salah satu ciri bangsa Indonesia adalah kemajemukan. Kemajemukan dalam artian keberagaman baik dari segi etnis, agama, serta keragaman budaya. Menariknya, Indonesia sebagai salah satu negara yang paling majemuk berdiri diatas perbedaan telah hidup secara berdampingan berabad-abad. Melintasi perjalanan sejarah, bahkan menjadi ciri khas yang telah di kenal oleh dunia internasional. Melalui slogan kebangsaan yang telah menjadi jati diri Bangsa, Bhinneka Tunggal Ika, sebuah ekspresi politik yang tidak hanya menjadi simbol negara tetapi lebih dari itu, gagasan tersebut merupakan pesan politik terhadap dunia internasional, jika betapun beragamnya Indonesia adalah negara dengan satu kesatuan politik yang tidak terpisahkan.

Bahkan banyak yang kemudian mengatakan jika keanekaragaman yang baik berupa etnik, agama, bahasa, dan budaya merupakan aset yang berharga untuk meningkatkan kreatifitas bangsa Indonesia. Apalagi ratusan etnik yang tersebar di Nusantara memiliki territorial (laut dan darat) yang kaya dengan sumber daya alam yang tiada duanya di dunia. Sungguhpun keanekaragaman itu mengandung potensi akan terjadinya konflik, tetapi tidak perlu disatukan dengan sistem yang otoriter. ${ }^{1}$

Keberagaman dan multikulturalisme telah menjadi keniscayaan bagi bangsa Indonesia.Tetapi, pada sisi yang lain. keberagamandan multikulturalisme bukan tidak mungkin menjadi ancaman yang sangat nyata bagi bangsa Indonesia. Sehingga bukan tidak mungkin, justru lewat keberagaman akan mendatangkan malapetaka, seperti konflik sosial dan gejolak sosial lainnya.Kecuali jika, keniscayaan keberagaman dapat di kelola dengan manusia-manusia yang bijaksana.Merujuk pada penjelasan alqu'an. Dimana didalam Islam dijelaskan bahwa manusia diciptakan di bumi untuk menjadi pemimpin sebagaimana ayat yang terdapat dalam Qur'an Surah Al-Baqarah 2:30: "Ingatlah ketika Tuhanmu berfirman kepada para malaikat: "Sesungguhnya Aku hendak menjadikan

\footnotetext{
${ }^{1}$ Said Agil Husin Al Munawar, MA, Fikih Hubungan Antar Agama, (Jakarta Selatan: Ciputat Press,2003), h. 162.
} 
seorang khalifah di muka bumi". Mereka berkata: "Mengapa Engkau hendak menjadikan (khalifah) di bumi itu orang yang akan membuat kerusakan padanya dan menumpahkan darah, padahal kami senantiasa bertasbih dengan memuji Engkau dan mensucikan Engkau?" Tuhan berfirman: "Sesungguhnya Aku mengetahui apa yang tidak kamu ketahui". 2

Pada konteks hari ini, penulis melihat betapapun keberagamaan yang hadir di bumi Indonesia adalah keniscayaan yang harus tetap dijaga. Meskipun, pada sisi yang lain masih saja ada beberapa oknum yang seringkali menggunakan isu perbedaan menjadi sebuah yang harus di takuti. Khususnya menjelang proses elektoral. pada lasimnya, di banyak tempat perbedaan dan keberadaan sering menjadi bahan perdebatan. Preferensi pemilih misalnya, tidak jarang pemilih menggunakan basis kedaearahan sebagai salah satu alasan memilih kandidat tertentu. Atau bahkan, menjadi keberagaman sebagai isu yang digunakan untuk menyerang dan menskerditkan seseorang.

Seiring dengan perjalanan demokrasi, memang multikulturalisme menjadi satu persoalan yang begtu massif dibicarakan khususnya Indonesia melewati orde baru menuju demokrasi. Mengingat bahwa apa yang kemudian berlangsung pada proses demokrasi bertautan dengan kebebasan yang seringkali di maknai sebagai kebebasan tanpa batas. Karena di maknai kebebsan sebagai kebebasan tanpa batas, maka persoalan pemilih pun tidak luput dari gaung soal kebebasan. Namun, dalam hal ini kebebasan yang dimakud lebih kepada kebebasan berbicara. Termasuk dalam kaitannya untuk menyudutkan seseorang entah karena lawan politik atau karena alasan kebencian dengan tendensi kebudayaan, seperti asal, suku dan warna kulit.

Lambat laun, transformasi politik elektoral kitapun semakin menakutkan. Meskipun fase ini berangsurangsur membaik. Khusus pada fenomena di banyak tempat, yang misalnya tidak lagi menggunakan tendensi multikulturalisme sebagai bahan pokok untuk mengeskpresikan kebencian namun sebaliknya justru di jadikan sebagai sebuah pemersatu sebagaimana yang di kehendaki oleh gagasan Bhinneka Tunggal Ika yang telah mendarah daging di Indonesia.

\footnotetext{
${ }^{2}$ Departemen Agama RI, Al-Qur'an dan Terjemahannya, (Bandung: Syaamil Al-Qur'an, 2005), h. 6.
}

Salah satu contoh wujud transformasi politik misalnya pada perhatian banyak kandidat yang telah melirik model kampanye aspiratif sebagai salah satu strategi politik untuk memikat pemilih. Model kampanye aspiratif ini di tuangkan dengan justru menjadikan alasan keberagaman sebagai sesuatu hal yang harus di wadahi. Karena itu, menjadi sebuah keharusan bahwa masing-masing daerah setidaknya sebagai pemilih harus memapu mengindentifikasi keunikan budaya yang dimiliki untuk kemudian bisa di salurkan melalui saluran politik. Hal ini sejalan dengan firman Allah dalam surah Asy-Syura/26: 38:"Dan (bagi) orang-orang yang menerima (mematuhi) seruan Tuhannya dan mendirikan shalat, sedang urusan mereka (diputuskan) dengan musyawarahantara mereka; dan mereka menafkahkan sebagian dari rezki yang Kami berikan kepada mereka."3

Ayat ini menjelaskan hak-hak rakyat atau masyarakat untuk melakukan kontrol terhadap pemerintah secara cermat. Sedangkan pemerintah hendaknya bermusyawarah dengan rakyat menghargai aspirasinya, dengan mengambil yang baik dari masukan-masukannya.

Kabupaten Luwu Timur merupakan kabupaten yang bisa dikategorikan sebagai Indonesia mini dikarenakan suku dan ras yang berada di kabupaten ini sangat beragam sehingga nuansa kekeluargaan dalam bingkai kemajemukan pun berhasil diciptakan. Kemenangan Thoriq Husler dalam pilkada 2015 merupakan kemenangan bersih tanpa proses money politik, hal ini terjadi karena program-program kerja unggulan yang ditawarkan oleh pasangan ini yang betul-betul pro rakyat, serta pendekatan Thoriq Husler kepada masyarakat Luwu Timur sangatlah baik karena beliau tidak memandang perbedaan ras, suku, serta agama. Karena hal inilah sehingga Thoriq Husler dapat memenangkan Pilkada di Luwu Timur di tengahtengah perbedaan etnis. ${ }^{4}$

\section{TINJAUAN PUSTAKA}

Sebelum menjelaskan lebih jauh, penulis telah melakukan penelusuran literatur yang memiliki kaitan dengan penelitian ini. Adapun tulisan yang hampir sama atau bahkan mirip dengan judul penelitian ini adalah sebagai berikut:

\footnotetext{
${ }^{3}$ Departemen, h. 369.

4 Batara Pos, Kemenangan Thoriq Husler-Irwan Bahri dalam Pilkada Luwu Timur 2015, (Malili: Batara Pos, 2015), h. 1.
} 
M. Nawawi, Haslinda B. Anriani, dan Ilyas menulis tentang "Dinamika Etnisitas dan Konflik Politik pada Pemilukada", dengan fokus penelitian menggali dan mengidentifikasi berbagai bentuk politik identitas etnik dan konflik politik yang terjadi di Kabupaten Poso selama kurun waktu pelaksanaan Pemilukada, tahun 2010. ${ }^{5}$ Sementara itu, Muhtar Haboddin menulis tentang "Menguatnya Politik Identitas di Ranah Lokal", dengan fokus penelitian wacana mengenai politik etnis kembali menguat semenjak reformasi di negeri ini digulirkan. Menurut Muhtar "Era reformasi telah menghantarkan bangsa ini ke arah keterbukaan, demokratisasi, otonomi daerah dan desentralisasi ternyata telah melahirkan kembali dan memperkuat kesadaran etnis. Gerakan politik etnisitas ini semakin jelas wujudnya. Bahkan banyak aktor politik lokal maupun nasional secara sadar menggunakan isu ini dalam power-sharing. Praktik politik etnis secara nyata menunjukkan bahwa betapa ampuhnya isu ini digunakan oleh aktor-aktor politik, ketika berhadapan dengan entitas politik lain". Seperti yang diungkapkan oleh Muhtar Haboddin yang mengatakan bahwa: Politik etnisitas digunakan untuk mempersoalkan antara, "kami" dan "mereka", "saya" dan "kamu" sampai pada bentuknya yang ekstrim "jawa" dan "luar jawa" atau "islam" dan "Kristen". Dikotomi oposisional semacam ini sengaja dibangun oleh elit politik lokal untuk menghantam musuh ataupun rival politiknya yang notabene "kaum pendatang". 6

Sementara itu menurut Adi Wijoyo menulis tentang "Manifestasi Identitas Politik Pada Pilkada Langsung Kabupaten Tulang Bawang Tahun 2012", dengan fokus penelitian ini lebih mengkaji manifestasi politik etnis yang digunakan oleh calon Bupati dan Wakil Bupati untuk dapat mengarahkan dan menentukan pilihan politik masyarakat melalui perasaan masyarakat terhadap sang calon tersebut. Identitas etnis yang direpresentasikan dalam proses politik dilakukan oleh calon guna memberikan pemahaman kepada masyarakat jika dirinya memiliki kesamaan dan merupakan bagian dari kelompok sosial di masyarakat. Dalam hal ini sang calon yang menggunakan identitas etnisnya secara simbolis, baik dalam perilaku hidup maupun aktivitasnya secara visual agar orang lain memiliki kejelasan tentang siapakah diri kita sebenarnya.

\footnotetext{
${ }^{5}$ M. Nawawi,Haslinda B. Anriani, dan Ilyas, "Dinamika Etnisitas dan Konflik Politik pada Pemilukada", Media Masyarakat, Kebudayaan dan Politik, Vo. 25 No. 3 (Juli 2012).

${ }^{6}$ Muhtar Haboddin, "Menguatnya Politik Identitas di Ranah Lokal", Jurnal Studi Pemerintahan, Vol.3 No.1 (Februari 2012), h. 118 .
}

Artinya melalui simbol-simbol etnis itulah kemudian masyarakat dapat mengidentifikasi sang calon dan mendefinisikan bahwa "bagaimana saya berbeda dengan sang calon" dan dari sinilah dapat diketahui "apakah kita sama dengan sang calon". Dalam politik identitas tentu saja ikatan kesukuan mendapat peranan penting, ia menjadi symbolsimbol budaya yang potensial serta menjadi sumber kekuatan untuk aksi-aksi politik. ${ }^{7}$

Terakhir menurut Denny Riswanda dalam tulisannya tentang "Revitalisasi Kekuatan Dewan Adat Dayak Kalimantan Tengah Dalam Rangka Meraih Otonomi Politik: Kajian Tentang Pemilukada Kota Palangkaraya Tahun 2013”, dengan fokus penelitian pada pilkada di Kota Palangkaraya karena dianggap mampu mewakili revitalisasi kekuatan yang dilakukan oleh dewan adat Dayak di era multikulturalisme dan kompetisi pemilukada. Hasil penelitian ini menyatakan bahwa dewan adat Dayak sebagai representasi dari masyarakat Dayak dan revitalisasi yang mereka tempuh untuk membuktikan eksistensi kepada masyarakat luas dan memperkuat komunitas dari dewan adat Dayak denganmemanfaatkan momentum politik multikulturalisme untuk merevitalisasi kekuatan mereka atas kesempatan minim yang terjadi di era orde baru, membuktikan bahwa komunitas adat ini ada dan menjadi bagian kehidupan sosial masyarakat. $^{8}$

Berdasarkan beberapa hasil penelitian yang telah dikemukakan di atas, dapat disimpulkan bahwa dari hasil penelitian tersebut bahwa secara keseluruhan berbeda, baik dari segi persepsi kajian maupun dari segi metodologi. Dalam hal ini peneliti lebih berfokus pada pengaruh multikultularisme di Luwu Timur terhadap kemenangan Thoriq Husler dalam pilkada 2015.

\section{TINJAUAN TEORETIS}

\section{Teori Perilaku Politik}

Perilaku politik adalah tindakan atau kegiatan seseorang atau kelompok dalam kegiatan politik.

${ }^{7}$ Adi Wijoyo, "Manifestasi Identitas Politik Pada Pilkada Langsung Kabupaten Tulang Bawang Tahun 2012", Skripsi, (Yogyakarta:Program Studi Pendidikan Kewarganegaraan dan Hukum, Fakultas Ilmu Sosial, Universitas Negeri Yogyakarta, 2013), h. v.

${ }^{8}$ Denny Riswanda, "Revitalisasi Kekuatan Dewan Adat Dayak Kalimantan Tengah Dalam Rangka Meraih Otonomi Politik: Kajian Tentang Pemilukada Kota Palangkaraya Tahun 2013", Tesis, (Surabaya: Program Magister Ilmu Politik Peminatan Analisis Politik, Fakultas Ilmu Sosial dan Ilmu Politik, UniversitasAirlangga, 2013), h. vii. 
Ramlan Surbakti mengemukakan bahwa perilaku politik adalah sebagai kegiatan yang berkenaan dengan proses pembuatan dan keputusan politik. Perilaku politik merupakan salah satu unsuratau aspek perilaku secara umum. Perilaku politik meliputi tanggapan internal seperti persepsi, sikap, orientasi dan keyakinan serta tindakan-tindakan nyata seperti pemberian suara, protes, lobi, dan sebagainya. Persepsi politik berkaitan dengan gambaran suatu obyek tertentu, baik mengenai keterangan, informasi dari sesuatu hal, maupun gambaran tentang obyek atau situasi politik dengan cara tertentu. ${ }^{9}$

\section{Teori Politik Identitas}

Politik identitas merupakan konsep baru dalam kajian ilmu politik. Politik identitas adalah nama lain dari biopolitik dan politik perbedaan. Biopolitik mendasarkan diri pada perbedaanperbedaan yang timbul dari perbedaan tubuh. Identitas melekat pada individu dan komunitas. Identitas merupakan karakteristik yang membedakan antara orang yang satu dengan dengan orang yang lain agar orang tersebut dapat dibedakan dengan yang lain dan dapat mencitrakan kepribadian seseorang.

Agnes Heller mengambil definisi politik identitas sebagai konsep dan gerakan politik yang fokus perhatiannya adalah perbedaan (difference) sebagai suatu kategori politik yang utama. Didalam setiap komunitas, walaupun mereka berideologi dan memiliki tujuan bersama, tidak bisa dipungkiri bahwa didalamnya terdapat berbagai macam individu yang memiliki kepribadian dan identitas masing-masing. ${ }^{10}$

\section{Teori Multikulturalisme}

Bikku Parekh mengategorikan konsep multikulturalisme ke dalam tiga bagian pokok. Pertama,perbedaan subkultur (subculture divesity), yaitu individu atau sekompok masyarakat yang hidup dengan cara pandang dan kebiasaan yang berbeda dengan komunitas besar dengan sistem nilaiatau budayapada umumnya yang berlaku. Kedua, perbedaan dalamperspektif (perspectival diversity) yaitu individu atau kelompok dengan perspektif kritis terhadap mainstreamnilai atau budaya mapan yang dianut oleh mayoritas masyarakat di sekitarnya.Ketiga,perbedaan

\footnotetext{
9 Ramlan Surbakti, Memahami Ilmu Politik,(Jakarta: Grasindo, 1999), h. 130.

${ }^{10}$ Ubed Abdillah, Politik Identitas Etnik: Pergulatan Tanda Tanpa Identitas, (Magelang: Indonesatera, 2002), h. 16.
}

komunalitas (communal diversity),yakni individu atau kelompok yang hidup dengan gaya hidup yang genuinesesuaidengan identitas komunal mereka (indigeneous people way of life). ${ }^{11}$

\section{METODE PENELITIAN}

Penelitian ini berlangsung di Luwu. Metode penelitian yangdigunakan adalah kualitatif. Teknikpengumpulan data di lakukan melalui observasi dan wawancara secara intensif. Wawancara dilakukan kepada beberapa pihak yang dirasa kompeten pada tema penilitian. Untuk bisa menentukan mana informan yang kompoeten, terlebih dahulu dilakukan proses identifikasi. Proses identifikasi dilakukan dengan mencari informasi terlebih dahulu orang-orang dekat dan orang kepercayaan bakal kandidat. Begitu diperoleh, peneliti langsung memberikan beberapa pertanyaan. Tujuannya untuk menggali lebih jauh informasi mengenai kandidat. Selain itu, agar informasi yang di peroleh berimbang. Saya juga melakukan konfrontasi dengan beberapa informal yang bertolak belakang dengan kandidat.

Dalam hal ini mereka yang tidak mendukung kandidat. Tujuan konfrontasi ini untuk mendapatkan informasi yang lebih kompleks mengenai kepribadian kandidat. Sekaligus untuk mengetahui sejauhmana kandidat menggunakan isu multikulturalisme sebagai salah satu strategi untuk memenangkan kandidat di jalur pemilu.

\section{HASIL DAN PEMBAHASAN}

\section{Luwu Timur dari Dekat}

Adat istiadat yang menonjol di Kecamatan Tomoni terdapat pada acara perkawinan, kebudayaan yang menonjol khususnya yang lebih spesifik lagi adalah kebudayaan atau adat suku Pamona dan Padoe. Mengenai kelengkapan-kelengkapan pakaian atau seserahan yang harus dibawa pada pihak mempelai wanita harus lengkap yang terdiri atas lemari, baju, sarung, pakaian dalam, dan bahan-bahan yang dipakai untuk memakan sirih yang terdiri atas kapur sirih, daun sirih, buah pinang, dan tembakau. Dan juga hewan sembelihan. Setelah persyaratan tersebut terpenuhi atau lengkap maka diserahkan oleh mempelai wanita oleh pengurus adat. Karena pada umumnya masyarakat pamona, padoe menganut agama Nasrani, maka akan melakukan

11 Bhikhu Parekh, Rethingking Multiculturalism: Cultural Diversity and Political Theory (Cambridge: Harvard University Press, 2000), h.3-4. 
prosesi pernikahan di Gereja yang disaksikan para pengurus adat, sesepuh, dan kedua mempelai. Setelah itu, pengantin diiring menuju tempat diadakannya resepsi perkawinan secara umum. Maka acara pernikahan tersebut berlangsung secara umum yang ada di daerah Luwu Timur. Pada malam harinya diadakan kegiatan dero. Dero merupakan salah satu jenis tarian tradisional masyarakat suku Pamona. Tarian ini tergolong tarian pergaulan yang ditarikan secara massal oleh semua kalangan masyarakat, baik pria maupun wanita, baik tua maupun muda bisa melakukan tarian ini.

Kemudian untuk agama, mayoritas penduduk kecamatan Tomoni beragamaIslam. Kondisi ini antara lain dapat dilihat dari banyaknya tempat ibadah bagi umat Islam seperti tersedia 32 masjid dan 24 mushallah. Selain itu penduduk kecamatan Tomoni terdapat komunitas masyarakat yang memeluk agama Kristen dengan jumlah tempat ibadah sebanyak 26 gereja.

\section{Biografi Singkat Thoriq Husler}

Ir. H. Muh. Thoriq Husler putra kelahiran Palopo, 19 April 1963. Husler tinggal di Jl. DR Sam Ratulangi Desa Puncak Indah Kecamatan Malili Kabupaten Luwu Timur. Husler tercatat sebagai alumni dari Fakultas Pertanian Universitas Pembangunan Nasional "Veteran" Yogyakarta tahun 1988. Pria yang kemudian lulus SMA pada tahun 1982 mempersitri wanita cantik yaitu Dra. Hj. Puspawati.

Karier di organisasi, Husler pernah menjabat sebagai Ketua FKPPI Kab. Luwu Timur, Ketua Palang Merah Indonesia (PMI)Ka.Luwu Timur, Ketua Badan Narkotika Kabupaten (BNK) Kab. Luwu Timur, Kosgoro Kab. Luwu Timur, Ketua Dewan Mesjid Kab. Luwu Timur, Ketua Himpunan Keluarga Tani Indonesia (HKTI) Kab. Luwu Timur, Ketua Himpunan Persaudaraan Haji Indonesia (HPHI) Kab. Luwu Timur, Ketua Kwartir Cabang Pramuka Kab. Luwu Timur, Ketua Badan Amil Zakat Kab. Luwu Timur.

Pengalaman organisasi membuat Husler sangat lihai dalam organisasi. Hal ini terbukti dari pengalaman organisasi Husler yang juga tidak sedikit. Setidaknya Husler pernah bekerja sebagai sekretaris Bappeda Kab. Manatutu Prov. TimorTimur tahun 1994-1999, Kepala Seksi Pembangunan Desa Kab. Luwu Utara tahun 20002001, Kepala Bidang Ekonomi Bappeda Kab. Luwu Utara tahun 2001-2003, Kepala Dinas
Koperindag dan Penanaman Modal Kab.Luwu Timur tahun 2003-2005, Kepala Dinas PU dan Penataan Ruang Kab. Luwu Timur tahun 20052009, Kepala Dinas Energid an Sumber Daya Mineral Kab. Luwu Timur tahun 2008-2010, Wakil Bupati Kab.Luwu Timur Periode 2010-2015. ${ }^{12}$

Kemudian untuk kampung halaman, perjuangan dan jasa Thoriq Husler bagi masyarakat Luwu Timur pada umumnya yaitu salah satu diantaranya adalah mengembangkan kawasan ternak Luwu Timur ke levelnasional. Berbagai upaya dan kiat yang pernah dilakukan oleh Husler untuk mensejahterakan masyarakat. Selain itu juga Husler banyak mendukung kegiatan-kegiatan masyarakat baik dibidang pendidikan, pemerintahan, dan sosial yang memiliki nilai positif bagi kehidupan masyarakat.

\section{Thoriq Husler di Masyarakat Multikultur}

Manusia adalah makhluk sosial dan makhluk budaya. Manusia selalu ingin melakukan kerjasama dan interaksi sosial. Interaksi itu tidak hanya dipicu oleh dorongan kebutuhan ekonomis, biologis, emosional, dan sebagainya yang mengikat dirinya, melainkan juga sebagai fitrah yang tak terbantahkan pada dirinya. Dengan demikian, ungkapan yang mengatakan bahwa manusia sebagai makhluk sosial adalah klaim substansial dan bukan sloganitas dan propagandailmiah dari ilmu-ilmu sosial. $^{13}$

Fitrah manusia untuk melakukan interaksi sosial dipicu oleh dorongan-dorongan kepentingan dan kebutuhan manusia terhadap satu sama lainnya. Seorang manusia tidak bisa hidup layak hanya bermodalkan dirinya sendiri atau bermodalkan kerjasama sebatas keluarga kecilnya. Kebutuhan terhadap berbagai benda dan bermacam jenis bantuan memerlukan adanya kerjasama yang lebih luas antara satu individu dengan individu yang lain; antara satu keluarga kecil dengan keluarga kecil lain; antara satu komunitas dengan komunitas yang lain; antara satu bangsa dengan bangsa yang lain, begitulah seterusnya. ${ }^{14}$

Dengan demikian, karakteristikyang ada dalam masyarakat terutama terletak pada kelompok manusia yang bebas dan kekal, menempati kawasan tertentu, memiliki kebudayaan serta terjalin dalam suatu hubungan di antara anggota-

\footnotetext{
${ }^{12}$ http://mth.center/ (diakses 2 Juli 2017)

${ }^{13}$ Said, h. 87.

${ }^{14}$ Said, h. 88.
} 
anggota yang ada didalamnya.Bapak Juslin Rongre Tangoa (etnik Pamona) mengatakan bahwa:

“suku Jawa, suku Sunda dan suku Bali merupakan angkatan transmigrasi di tahun 1980-an serta pada masa penjajahan merupakan tenaga rodi belanda di tahun 1930an yang hingga kini menjadi penduduk tetap yang ikut membagun dan memajukan daerah Luwu Timur. Suku Jawa paling banyak jumlahnya yaitu sekitar 30 persen dari total penduduk Luwu Timur. Sedangkan suku Pamona dan Padoe merupakan penduduk asli Luwu Timur. "15

Pada satu sisi multikulturalisme mensyaratkan adanya kesadaran dari setiap individu ataupun kelompok, baik yang didasari atas kesamaan agama, etnis, dan budaya untuk menghargai keberadaan individu ataupun kelompok yang lain. Ini merupakan kondisi ideal suatu masyarakatmultikultural. Apabila keanekaragaman agama, etnis, dan budaya tidak saja diakui, tetapi juga diberikan ruang untuk mengembangkan diri dan mengartikulasikan identitasnya dalam kerangka kesetaraan dan keadilan. ${ }^{16}$ Sebagaimana hasil wawancara sayadengan pak Kornelius Lante (etnik Toraja) yang mengatakan bahwa:

"Kalau disini masyarakat hidup rukun, tanpa melihat adanya perbedaan suku ataupun agama, toleransi antar umat beragama disini sangatlah kuat, kita saling menghargai dan menghormati budaya atau kebiasaan-kebiasaan masyarakat disini yang berbeda dengan kita, ini dapat terpelihara bertahun-tahun karena kita sadar kita tidak hidup sendiri disini pasti nantinya kita akan membutuhkan bantaun orang lain. "17

Hal serupa juga dikatakan oleh pak Zaenal (Etnik Jawa) yang mengatakan bahwa: Kami disini itu sama semua, kami tidak membeda-bedakan orang bali, orang jawa, ataupun orang bugis.Di Tomoni itu dijuluki sebagai Indonesia mini karna banyak sekali suku yang tinggal disini dan kamipun hidup berdampingan dengan baik. "18

\footnotetext{
15 Juslin Rongre Tangoa (45 tahun), Guru SDN 175 Kawarasan, Wawancara, Tomoni, 20 Oktober 2017.

16 H.A.R. Tilaar, Multikulturalisme TantangantantanganGlobal Masa Depan dalam Transformasi Pendidikan Nasional, (Jakarta: Grasindo, 2004), h. 83.

${ }^{17}$ Kornelius Lante (48tahun), Guru SDN 175 Kawarasan, Wawancara, Tomoni, 20 Oktober 2017.

${ }^{18}$ Zaenal (52tahun), Wiraswasta, Wawancara, Tomoni, 30 Oktober 2017.
}

Sekiranya hal inilah menjadi modal untuk lebih mengokohkan masyarakat dalam bingkai multikultural. Kehidupan masyarakat diwarnai dengan keanekaragaman yang kompleks, tetapi tetap menjadi satu kesatuan yang utuh.Penguatan pada nilai-nilaiperbedaan sukumaupun agamayangmengakibatkan terbentuknya sikap yang berbeda-beda dari setiap individu didalam masyarakat yang menjadi sangat penting untuk dikaji agar mampu mewujudkan kehidupan yangharmonis dan menciptakan kesatuan yang kuat agar dapat terwujud kehidupanyangadil dan makmur.

Hubungan antar masyarakat dengan kebudayaan yang paling realistis ditunjukkan melalui keberadaan kebudayaansebagai wadahuntuk mempertahankan masyarakat dari berbagai ancaman yang menghadang mereka. Kebudayaan bisa menginformasikan tentang nilai dan beberapa peristiwayang terjadi di masa lalu, sekarang, dan akan dating, serta kebudayaan mengajarkan kepada setiap manusia tentang apa yang harus dibuat oleh generasi manusia.

Dalam konteks ini, kerukunan antar etnis dan agama serta sikap toleransi adalah aktualisasi nilai kebangsaan yang mampu dieksplorasi dan diproyeksikan secara arif dan bijak oleh pemerintah daerah dan masyarakat Luwu Timur, sehingga kemajemukan sosial dan keterbukaan serta saling menghormati antara satu komunitas dengan komunitas yang lain terjalin secara harmonis menjadi bagian pilar dari pembangunan di kabupaten Luwu Timur.

\section{Sosok Thoriq Husler di Mata Masyarakat}

Sosok Thoriq Husler merupakan seorang figur bagi semua kelompok masyarakat. Beliau dapat dijadikan sebagai panutan dalam masayarakat.Hal tersebut telah terlihat dalam aktifitas sehari-hari dari Thoriq Husler, sebagaimana wawancara yang telah penulis lakukan dengan ibu $\mathrm{Hj}$. Kasih Jumadi (etnik Jawa) yang mengatakan bahwa:

"Kalau dipikir kan pak aji itu bukan orang jawa tapi dia mampu mengambil hati kami disini orang jawa. Dia langsung turun ke lapangan dengan cara melakukan pendekatan dengan masyarakat contohnya seperti, datang di pesta-pesta. Sedangkan masyarakat di desa kan istilahnya masyarakat awam. Istilahnya sumber daya masyarakatnya kurang, jadi mereka mencerna politk hanya dengan hal-hal seperti itu dengan pendekatan seperti itu. Kalau berbicara ideologi 
orang-orang di desa itu tidak nyambung. Jadi dengan pendekatan begitu bisa mendapatbasis suara disini. Hampir 90\% pak Husler memperoleh suara disini. Adapun calon lain itu kayak haji Nur dan pak badar itu jarang di kenal disini. Kan di samping butuh finansial seorang pejabat politik itu butuh popularitas. Kayak macam-macam artis kemarinkan naik karna popularitasnya tinggi. Kan berkesan di hatinya kayak Pasha Ungu, lolosmi. Soal kesukuan, etnis, agama itu jarang disini. Wong disini aman tentram, ndak sama kayak di daerah yang lain toh disini aman." 19

Hal sepadan juga hampir sama dikatakan oleh pak Zainuddin (etnik Padoe) yang mengatakan bahwa:

"Jika biasanya kita memilih lantaran adanya kesamaan suku atau agama dari pasangan calon maka di Luwu Timur itu tidak terjadi, sama halnya dengan adanya hubungan keluarga, itu tidak ada kaitannya sama sekali, tetapi masyarakat memilih karna memang benar-benar sesuai dengan hati nurani mereka. Selama ini juga kita lihat ketika bapak Thoriq Husler menjabat sebagai wakil bupati sebelumnya, beliau melakukan kinerja yangluar biasa sehingga masyarakat puaslah dengan hasil kerjanya. Jadi disini hubungan etnik tidak berpengaruh karna kami masyarakat disini tidaklah memilih karna adanya persamaan. Yang jelas kita memilih itu yang dasarnya semua orang liat yang baik dan yang bisa kita rasakan manfaatnya., 20

Berdasarkan pernyataan dari hasil wawancara di atas, penulis menemukan bahwa para pemilih memilih calon bukan karena memiliki latar belakang etnis yang sama akan tetapi mereka melihat dari segi kualitasnya. Karena dalam masyarakat yang homogen secara kultural, setiap individu sama-sama memiliki kebutuhankebutuhan, norma-norma, motivasi, adat istiadat sosial, dan pola tingkah laku yang mirip secara luas. $^{21}$ Hal ini telah membuktikan jika Thoriq Husler dapat merangkul semua masyarakat dari kalangan manapun tanpa membedakan latar belakang etnis.Fenomena para pelaku pemilih ini berorientasi pada pesona seorang figur yang modal utamanya adalah membangun relasi dan kepercayaan masyarakat. Hal tersebut diperkuat

19 Hj. Kasih Jumadi (49 tahun), Kepala SDN 175 Kawarasan, Wawancara, Tomoni, 20 Oktober 2017.

20 Zainuddin (47tahun), Guru SDN 175Kawarasan, Wawancara, Tomoni, 30 Oktober 2017.

${ }^{21}$ Bhikhu Parekh, h. 321. dengan pernyataan pak Satria. S (etnik Lombok) yang mengatakan bahwa:

"Dalam berkecimpung dengan masyarakat dia itu tidak memihak, betul-betul dia nasionalisme. Tidak melihat darimana kamu berasal. Kamu suku apa, itu tidak ada sama sekali. Kemudian apabila mendapat pernyataan atau usulan oleh masyarakat beliau tidak langsung menjawab saya sanggup tetapi beliau mengatakan Insya Allah saya akan menyanggupi usulan bapak apabila saya bisa, akan saya usahakan. Beliau tidak pernah menekankan diri untuk bisa mendapat simpati dari masyarakat, semua usulan masyarakat beliau terima tetapi tidak langsung disanggupi.,"22

Dari beberapa hasil wawancara di atas dapat disimpulkan bahwa sosok Thoriq Husler dapat merangkul semua kalangan masyarakat dalam di Luwu Timur. Komunikasi yang dibangun antara sosok figur dan masyarakat sangatlah baik, ini merupakan pembentukan makna yang dibangun oleh pasangan calon untuk menarik simpati masyarakat.

\section{Kemenangan Thoriq Husler}

Setiap manusia yang ada dalam setiap kolektifitas komunitasnya akan senantiasa kental dengan obsesi dan kehendaknya akan sebuah kekuasaan (power). Hal tersebut merupakan kodrat yang telah dimiliki sebagai sebuah kelebihan dari aspek kemanusiaansehingga akan selalu terdapat keterkaitan antara budaya dan politik.Bugisyaitu ibu A. Minarni yang mengatakan bahwa:

"Masyarakat Luwu Timur dapat hidup rukun padahal Luwu Timur bisa dikatakan sebagai Indonesia mini karena masyarakatnya yang bermacam-macam suku. Akan tetapi keberagaman ini tidak berlaku dalam pilkada kemarin, buktinya saya orang bugis tidak memilih calon bupati yang memiliki latar belakang suku yang sama dengan saya.",23

Kemudian, bapak Wayan Slametselaku tim kampanye dari pasangan Husler Irwan yang mengatakan:

"Selama ini mereka (Husler-Irwan) tidak pernah membeda- bedakan masyarakat dari kalangan

\footnotetext{
${ }^{22}$ Satria. S (42tahun), Pegawai, Wawancara, Tomoni, 30 Oktober 2017.

23 A. Minarni (42tahun), Guru SDN 175 Kawarasan, Wawancara, Tomoni, 20 Oktober 2017.
} 
kaya maupun miskin. Pak Husler bukan asli Luwu Timur, jadi dalam baliho kampanye tidak ada kemarin kita bahas soal putra daerah. Pak Husler itu adalah calon yang paling tidak adauangnya, akan tetapi masyarakat banyak yang memilih karena telah dilihat dari kinerjanya waktu jadi wakil bupati, keramahannya dengan masyarakat yang membuat masyarakat memilihnya, karena setiap ada acara kematian baik itu yang meninggal agama islam, hindu, maupun kristen apabila pak Husler lewat pasti dia akan singgah. "24

Adapun, hasil wawancara penulis dengan bapak I Nyoman Suparta(etnik Bali), ditemukan juga bahwa perilaku masyarakat etnis Bali dalam memilih sudah tidak lagi melihat batasanetnis, seperti yang dikatakannya:

"Saya memilih pasangan nomor urut 3 memang karena saya telah melihat kinerjanya selama ini, walaupun mereka tidak satu suku dengan saya, akan tetapi bapak Thoriq Husler memang dapat merangkul seтиa suku di Luwu Timur tanpa ada yang dibeda-bedakan. "25

Akan tetapi ada juga beberapa kalangan masyarakat yang memilih Karena memang memiliki ikatan emosional seperti yang dikatakan oleh bapak Kornelius Lante (etnik Toraja) dalam wawancaranya yaitu:

"Rata-rata penduduk disini antusiaski ikut pemilu. Kemarin itu saya pilih nomor 1 dek karna kebetulan saya juga orang toraja karna begitumi toh kita tau kalau di desa hubungan kekerabatan masih kental. Jadi begitumi, kalau saya yang dekat sajalah karna tidak mungkin juga bukan samasamata orang toraja yang mau perhatikanki. ${ }^{, 26}$

Thoriq Husler Sebagai Simbol Pemersatu Keragaman atau multikulturalisme merupakan salah satu realitas utama yang dialami masyarakat Luwu Timur pada umumnya. Dari keragaman tersebut maka lahirlah sebuah komitmen untuk mengakui keragaman yang merupakan salah satu ciri dan karakter masyarakat Luwu Timur. Keragaman tidak lantas menjadi sumber kekacauan ataupun konflik yang berkepanjangan. Hal tersebut

24 Wayan Slamet (47 tahun), Wirausaha, Wawancara, Tomoni, 25Oktober 2017.

${ }^{25}$ I Noman Suparta(45 tahun), Guru SDN 175 Kawarasan, Wawancara, Tomoni, 20 Oktober 2017.

${ }^{26}$ Kornelius Lante (48tahun), Guru SDN 175 Kawarasan, Wawancara, Tomoni, 20 Oktober 2017. dikarenakan adanya simbol, nilai, struktur, dan lembaga dalam kehidupan bersama.

\section{Gagasan Pembauran}

Pembauran merupakan proses perubahan kebudayaan secara total akibat membaurnya dua kebudayaan atau lebih sehingga ciri-ciri kebudayaan yang asli atau lama tidak nampak lagi. Menurut Koentjaraningrat, pembauran adalah suatu proses sosialyang terjadi pada berbagai golongan manusia dengan latar belakang kebudayaan yang berbeda. Setelah mereka bergaul dengan intensif, sifat khas dari unsur-unsur kebudayaan masingmasing berubah menjadi unsur kebudayaan campuran.

Kebutuhan terhadap kerjasama sosial itu mengharuskan terjadinya interaksi dan perbauran diantara sesama manusia. Dalam masyarakat modern, pembauran dan interaksi tidak lagi sebagai batas ide sosial yang dikemukakan dalam ranah teoritis, melainkan telah menjadi keharusan dan kenyataan yang tak terbantahkan di belahan manapun di dunia ini. Percampuran dan pembauran dalam kehidupan sosial itu bukan hanya sebatas rasa atau suku melainkan juga dalam hal keyakinan agama. Pengingkaran terhadap kenyataan hubungan-hubungan sosial itu merupakan penolakan terhadap suatu keniscayaan hidup manusia itu sendiri. ${ }^{27}$

Penjelasan di atas sesuai dengan kondisi masyarakat Luwu Timur yang memiliki beragam etnis dan budaya termasuk keyakinan. Maka hal inilah merupakan salah satu kekuatan jika Thoriq Husler mampu berbaur dalam lingkungan masyarakat tersebut, dengan harapan dapat diterima dengan baik.Hal ini dikuatkan dengan sosok Thoriq Husler yang kesehariannya berbaur di masyarakat. Rasa toleransi dan simpatik yang tinggi kepada masyarakat sehingga beliau dicintai oleh semua kalangan. Sikap toleransi merupakan ciri kepribadian bangsa Indonesia.Sebagaimana yang dikatakan oleh Pak Wayan Slamet (etnik Bali) dalam wawancaranya:

"Itu pak Husler selalu turun ke masyarakat, kalau beliau ada waktu kosong biasanya beliau hadir di kegiatan-kegiatan sosial maupun keagamaan, beliau juga biasa hadir di acara ngaben disini, makanya Husler banyak dicintai oleh masyarakat

\footnotetext{
${ }^{27}$ Said, h. 88.
} 
Bali walaupun beliau itu muslim tapi tetap menghargai budaya kami.",28

Metode pembauran yang dilakukan oleh Thoriq Husler ternyata memiliki dampak yang positif dibuktikan dengan Thoriq Husler dapat diterima oleh semua kalangan etnis yang ada di Luwu Timur, dan hal inilah yangdijadikan sebagai modal serta kekuatan untuk mengumpulkan pundi-pundi suara pada pilkada tahun 2015. Ada beberapa faktor yang mempengaruhi hal tersebut, diantaranya adalah faktor toleransi, kesempatankesempatan dibidang sosial, sikap menghargai orang asing, dan kebudayaannya. Ini dibuktikan dengan hasil wawancara saya dengan bapak Wayan (Etnik Bali) yang mengatakan bahwa:

"Husler memang lebih banyak turun ke masyarakat, dan itu dilakukan sejak dulu sewaktu masih menjabat sebagai wakil bupati, dia selaluhadir dalam acara kematian, pesta atau acara syukuran. Kelebihannya juga Husler dia itu murah senyum, lembut dan tidak mudah marah, sehingga banyak masyarakat yang senang." 29

Sedangkan hasil wawancara saya dengan pak Juslin Rongre Tangoa (etnik Padoe) mengatakan bahwa:

"Semangat toleransi menjadi keutuhan masyarakat disini, saya bangga menjadi masyarakat disini karena di dalam perbedaan kita tetap saling menghargai, saya berharap kedepannya pemimpin yang akan memimpin kami tetap menjaga budaya kearifan lokal dan rasa toleran yang diwariskan oleh para leluhur sebelumnya.",30

Demikian pernyataan dari bapak Wayandan pak Juslinyang menggambarkan sosok Husler yang begitu fenomenal di mata masyarakat secara umum.Menjaga kerukunan dan toleransi dalam pergaulan hidup antar umat beragama merupakan salah satu usaha Husler untuk menciptakan keharmonisan hubungan manusia dalam masyarakat majemuk dan menciptakan kesatuan yang kuat agar dapat terwujud kehidupan yang adil dan makmur.

Bentuk hubungan diberbagai kalangan sangat penting untuk diperhatikan dalam masyarakat

\footnotetext{
28 Wayan Slamet (47 tahun), Wirausaha, Wawancara, Tomoni, 25 Oktober 2017.

29 Wayan (45 tahun), Petani, Wawancara, Tomoni, 26Oktober 2017.

30 Juslin Rongre Tangoa (45 tahun), Guru SDN 175 Kawarasan, Wawancara, Tomoni, 20 Oktober 2017
}

multikultural, karena tipe masyarakat ini tersusun oleh beragam etnik yang memiliki latar belakang yang berbeda. Ketika beragam etnik itu berkumpul, maka terjadilah masyarakat campuran yang dalam perkembangannya dapat berbaur antara masyarakat yang satu dengan masyarakat yang lainnya. ${ }^{31}$

\section{Kebijakan Thoriq Husler yang Pro Rakyat}

Kebijakan yang pro rakyat merupakan kebijakan yang bersifat solutif terhadap masalah-masalah yang dihadapi oleh rakyat, baik rakyat miskin, rakyat cukup mampu maupun rakyat dari golongan mampu dengan cara yang benardan bersifat mandiri. Kebijakan yang dimaksudkan bertujuan untuk membangun sinergi dengan berbagai pihak dalam rangka melakukan edukasi dan kontrol sosial, serta kegiatan yang sehat bersifat kreatif untuk menumbuhkan suasana kondusif dan produktif mewujudkan pembangunan manusia seutuhnya sebagaimana cita-cita pembangunan nasional yang berdasarkan Pancasila dan UUD 1945 dengan sistem NKRI yang bersifat Bhineka Tunggal Ika.

Dalam pilkada pada tahun 2015, Thoriq Husler menyampaikan beberapa visi dan misinya untuk menjadi calon bupati Luwu Timur. Diantaranya ada beberapa program atau kebijakan yang hendak dilaksanakannya yaitu dibidang agribisnis, kesehatan, dan pendidikan. Masyarakat Luwu Timur mendukung penuh kebijakan Thoriq Husler ini. Hal ini dibuktikan dengan hasil wawancara saya dengan saudara Amir yang mengatakan bahwa:

"Kami tahu bahwa kedepannya Thoriq Husler bakal calon Bupati maka dari itu kami akan membentuk tim kecil untuk mengajak bersama sama masyarakat Luwu timur guna untuk melakukan pergerakan mensosialisasikan bahwa pioneer Pro Rakyat yang di nantikan telah hadir dan siap memimpin Luwu Timur. Masyarakat Luwu Timur merindukan dan menantikan sosok pemimpin seperti beliau yang kepeduliannya terhadap masyarakat sangat tinggi dan kepeduliannya pula ingin membangun daerah ini yakni Bumi Batara guru ini dibuktikan saat duduk mendampingi Andi Hatta M sebagai wakil Bupati Luwu Timur, selain kepribadian beliau yang familiar, dermawan, serta tidak membeda bedakan satu sama lain baik dari kalangan mana

\footnotetext{
${ }^{31}$ Alo Liliweri, Prasangka dan Konflik: Komunikasi Lintas Budaya Masyarakat Multikultural, (Yogyakarta: LKIS, 2005), h. 138.
} 
pun, juga memiliki visi yang jelas untuk membangun Luwu timur yang lebih baik. "32

Sebagai daerah dengan potensi pertanian yang besar, Thoriq Husler mengaku optimis dapat mengembangkan Kabupaten Luwu Timur ke depan dengan adanya sumber daya dibidang pertanian. Husler melihat bahwa basis agribisnis terletak pada keberimbangan dan keberlanjutan, dengan disokong oleh aspek-aspek seperti ketersediaan bahan mentah, tingkat produksi, harga, dan kinerja pasar. Sedangkan dalam bidang pendidikan yaitu adanya program pendidikan gratis sampai jenjang perguruan tinggi dan adanya bantuan-bantuan yang berbentuk fisik bagi siswa dan siswi yang akan melanjutkan pendidikan serta adanya bantuan penunjang untuk meningkatkan kualitas pendidikan di Luwu Timur. Untuk bidang kesehatan Husler berjanji untuk memperbaiki infrasturktur dibidang kesehatan agar masyarakat bisa lebih nyaman dan mudah untuk mendapatkan perawatan kesehatan dan meningkatkan kompetensi tenaga medis dengan cara melanjutkan program studi pada tenaga medis. ${ }^{33}$

Kebijakan-kebijakan seperti itulah yang diinginkan oleh masyarakat setempat, kebijakan yang memang benar-benar pro rakyat, masyarakat berharap itu semua dapat terwujud jika nantinya Husler terpilih dalam pilkada tahun 2015. Sebagaimana yang dikatakan oleh pak Bayu (etnik Jawa) dalam wawancaranya yang mengatakan bahwa:

"Saya berharap kalau nanti Husler jadi bupati di Luwu Timur, beliau dapat meningkatkan mutu pendidikan disini, supaya tidak ada lagi anak-anak yang putus sekolah hanya karena masalah biaya., 34

Harapan masyarakat sangatlah besar terhadap kebijakan-kebijakan yang dijanjikan oleh Husler.Mereka sangat berharap jika nantinya Husler terpilih menjadi bupati, Luwu Timur akan menjadi lebih baik lagi, mutu pendidikan semakin meningkat sehingga akan jauh lebih baik dari sebelumnya, kemiskinan dapat teratasi, dan masalah-masalah sosial lainnya dapat dibenahi sehingga Luwu Timur menjadi suatu daerah yang ideal, walapun didalamnya terdapat perbedaanperbedaan akan tetapi semua itu dapat disatukan

32 Amir Rahman (23 tahun),Mahasiswa, Wawancara, Tomoni, 26Oktober 2017.

${ }^{33}$ Rakyatsulsel.com (Diakses 1 Juli 2017).

34 Bayu (25 tahun), Wiraswasta, Wawancara, Tomoni, 26Oktober 2017. karena karakter masyarakatnya yang mudah unutuk berbaur. Semua itu tidak akan ada artinya sama sekali tanpa adanya sosok pemimpin yang merakyat, maka dari itulah mereka berharap semoga Husler dapat terpilih karena memang beliaau adalah sosok figure dambaan masyarakat setempat.

\section{PENUTUP}

Hasil penelitian ini menunjukan bahwa pelaksanaan pilkada Luwu Timur tahun 2015, etnisitas tidak terlalu memainkan peranan penting karena sentimen etnis pemilih relatif kecil. Ada kedewasaan yang mulai tumbuh pada pemilih. Demokrasi yang berlangsung dengan situasi sosial masyarakat yang kemudian hidup dan aktifitas keseharian semakin plural menjadi salah satu alasan yang membuat setiman etnis relatife kecil. Seperti yang berlangsung di Luwu Timur, politik kewargaan yang berlangsung dalam aktifitas sehari-hari yang banyak terintegrasi dengan etnis lain membuat semakin menguatnya rasa kebersamaan. Disaat yang sama, momentum tersebut sebagai ruang ekspresi politik yang selanjutnya di gunakan untuk merajut kebersamaan. Sehingga ketika momentum Pilkada, keberagaman justru tidak di jadikan sebagai pemicu perpecahan.

Hasil penelitian ini setidaknya penting untuk melihat proses Pilkada yang akan berlangsung di Indonesia, bahwa benar dengan keberagaman yang telah menjadi keniscayaan Indonesia bisa menjadi dua sisi pedang. Pada sisi yang lain, keberagaman ketika tidak disikapi secara bijak dapat memicu konflik khususnya menjelasang dan pasca proses Pilkada. Namun ada sisi lainyang harus dilihat sebagaimana yang telah ditemukan pada penelitian ini, bahwa tendensi kebencian terhadap keberagaman bisa ditekan dengan sebuah praktek politik kewarganaan. Wujudnya dengan memperluas aktifitas politik kewargaan berbasisi komunitas tempat tinggal, bukan berbasis kedaerahan apalagis etnis.

$* * *$

\section{DAFTAR PUSTAKA}

Adi Wijoyo, "Manifestasi Identitas Politik Pada Pilkada Langsung Kabupaten Tulang Bawang Tahun 2012", Skripsi, (Yogyakarta:Program Studi Pendidikan Kewarganegaraan dan 
Hukum, Fakultas Ilmu Sosial, Universitas Negeri Yogyakarta, 2013).

Alo Liliweri, Prasangka dan Konflik: Komunikasi Lintas Budaya Masyarakat Multikultural, (Yogyakarta: LKIS, 2005).

Batara Pos, Kemenangan Thoriq Husler-Irwan Bahri dalam Pilkada Luwu Timur 2015, (Malili: Batara Pos, 2015).

Bhikhu Parekh, Rethingking Multiculturalism: Cultural Diversity and Political Theory (Cambridge: Harvard University Press, 2000).

Denny Riswanda, "Revitalisasi Kekuatan Dewan Adat Dayak Kalimantan Tengah Dalam Rangka Meraih Otonomi Politik: Kajian Tentang Pemilukada Kota Palangkaraya Tahun 2013", Tesis, (Surabaya: Program Magister Ilmu Politik Peminatan Analisis Politik, Fakultas Ilmu Sosial dan Ilmu Politik, UniversitasAirlangga, 2013).

Departemen Agama RI, Al-Qur'an dan Terjemahannya, (Bandung: Syaamil AlQur'an, 2005).

H.A.R. Tilaar, Multikulturalisme TantangantantanganGlobal Masa Depan dalam Transformasi Pendidikan Nasional, (Jakarta: Grasindo, 2004).

M. Nawawi,Haslinda B. Anriani, dan Ilyas, "Dinamika Etnisitas dan Konflik Politik pada Pemilukada", Media Masyarakat, Kebudayaan dan Politik, Vo. 25 No. 3 (Juli 2012).

Muhtar Haboddin, "Menguatnya Politik Identitas di Ranah Lokal", Jurnal Studi Pemerintahan, Vol.3 No.1 (Februari 2012).

Ramlan Surbakti, Memahami Ilmu Politik,(Jakarta: Grasindo, 1999).

Said Agil Husin Al Munawar, MA, Fikih Hubungan Antar Agama, (Jakarta Selatan: Ciputat Press,2003).

Ubed Abdillah, Politik Identitas Etnik: Pergulatan Tanda Tanpa Identitas, (Magelang: Indonesatera, 2002).

\section{Wawancara}

A. Minarni (42tahun), Guru SDN 175 Kawarasan, Wawancara, Tomoni, 20 Oktober 2017.

Amir Rahman (23 tahun),Mahasiswa, Wawancara, Tomoni, 26Oktober 2017.

Bayu (25 tahun), Wiraswasta, Wawancara, Tomoni, 26Oktober 2017.

Hj. Kasih Jumadi (49 tahun), Kepala SDN 175 Kawarasan, Wawancara, Tomoni, 20 Oktober 2017.

I Noman Suparta(45 tahun), Guru SDN 175 Kawarasan, Wawancara, Tomoni, 20 Oktober 2017.

Juslin Rongre Tangoa (45 tahun), Guru SDN 175 Kawarasan, Wawancara, Tomoni, 20 Oktober 2017.

Kornelius Lante (48tahun), Guru SDN 175 Kawarasan, Wawancara, Tomoni, 20 Oktober 2017.

Satria. S (42tahun), Pegawai, Wawancara, Tomoni, 30 Oktober 2017.

Wayan (45 tahun), Petani, Wawancara, Tomoni, 260ktober 2017.

Wayan Slamet (47 tahun), Wirausaha, Wawancara, Tomoni, 25 Oktober 2017.

Zaenal (52tahun), Wiraswasta, Wawancara, Tomoni, 30 Oktober 2017.

Zainuddin (47tahun), Guru SDN 175Kawarasan, Wawancara, Tomoni, 30 Oktober 2017.

\section{Website}

http://mth.center/ (diakses 2 Juli 2017)

Rakyatsulsel.com (Diakses 1 Juli 2017). 